\title{
Het communicatietalent van accountants
}

\section{Roger Dassen}

Wie had dat ooit gedacht? Je kunt geen krant openslaan of er staat wel ergens iets te lezen over accountants. Enron heeft als een ongelooflijke katalysator de discussie over accountants beïnvloed. De aantijgingen jegens het beroep zijn niet van de lucht. Er wordt niet meer goed gecontroleerd,

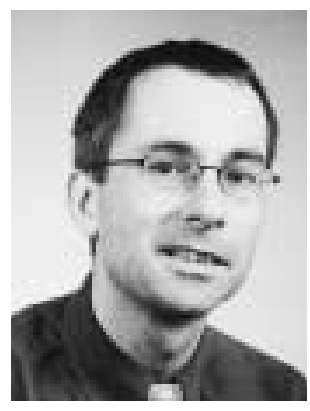
accountants bezwijken voor de verleidingen van consultancy, wie controleert er eigenlijk de accountants, het kan niet op. Hoe reageren nu de accountants zelf in de huidige crisissituatie?

De eerste categorie van reacties is die van 'wij weten nog niet precies wat er gebeurd is, en dus hebben wij nog niet echt een mening over de prestaties van onze collega's. Een reactie die primair is ingegeven vanuit de bezorgdheid voor goede collegiale verhoudingen, maar die voor het beroep weinig effectief is. Toen Karel Noordzij een paar dagen na zijn aantreden als topman van de NS werd geconfronteerd door een felle journalist met de ellende voor NS-passagiers van een vertraging in de Schipholtunnel, reageerde deze niet met 'dat moeten wij nog eens uitzoeken', maar door de boodschap van de journalist zelfs nog uit te vergroten: 'Het is verschrikkelijk, u hebt het alleen maar over de NS-passagiers, maar wat te denken van de ellende voor de vliegreizigers?' Het gevolg was een verslagen journalist, die een zorgvuldig opgebouwd schaakspel al in de eerste zet verloren zag gaan. Noordzij ontkende het probleem niet, hij knuffelde het dood. Helaas

Prof. Dr. R.J.M. Dassen RA is partner van Deloitte \& Touche Accountants en tevens hoogleraar Auditing aan de Universiteit Maastricht alsmede de Vrije Universiteit. Hij studeerde economie en accountancy aan de Universiteit Maastricht, waar hij in 1995 promoveerde. heb ik maar weinig accountants langs die lijn de Enron-kwestie horen becommentariëren: 'Als het werkelijk zo is dat accountants daar grove fouten hebben gemaakt, en zelfs wederrechtelijk bewijsmateriaal zouden hebben vernietigd, als het allemaal echt zo is, waarde journalist, dan is dat een grof schandaal.' Is een dergelijke uitspraak anticollegiaal? Natuurlijk niet. Een dergelijke uitspraak zegt niets over een kantoor, hooguit iets over een beperkt aantal individuen. Wel is zo'n statement een ook voor de buitenwereld tastbaar bewijs van het effectieve zelfreinigende vermogen van de accountants-professie.

De tweede categorie van reacties zit in de hoek 'wij moeten het publiek beter uitleggen wat wel en niet behoort tot de verantwoordelijkheden van accountants in het kader van een jaarrekeningcontrole.' Op zich niets mis mee, maar dit roepen wij al honderd jaar. En laten wij de hoop nu maar opgeven dat die lijn uiteindelijk de oplossing gaat brengen. Het publiek is niet geïnteresseerd in de omslachtige manier waarop het accountantsberoep aankijkt tegen haar fraudeverantwoordelijkheid, en het publiek zal niet ophouden om na ieder faillissement de vraag te stellen: 'waar waren de accountants?'

Deze bespiegelingen schoten door mijn hoofd toen ik onlangs een onderzoek las uit Nieuw-Zeeland naar de wijze waarop accountants in de algemene pers worden afgeschilderd. De onderzoekers hebben hiertoe alle publicaties over accountants in een aantal dagbladen over een periode van zeven jaar gerubriceerd. Hun belangrijkste conclusie is dat de belangstelling voor accountants in de media nogal digitaal van aard is. Aan de ene kant wordt de accountant veelal afgeschilderd als de 'elite expert', die zeer verheven boven de partijen vanuit een deskundige en onpartijdige positie zijn licht laat schijnen over een bepaalde kwestie. Aan de andere kant zien wij de accountant veelal terug als 'unethical player'. Neutrale artikelen over accountants of hun vakgebied zijn relatief zwaar ondervertegenwoordigd in de media. Op zoek naar de 
achtergrond van deze kennelijke vertekening in de mediabelangstelling komen de onderzoekers met een aantal interessante verklaringen. Allereerst ontwikkelt de berichtgeving binnen de algemene journalistiek zich steeds nadrukkelijker in de richting van infotainment. En infotainment gedijt nu eenmaal voortreffelijk in conflictsituaties, waarin een accountant hetzij als 'bad guy' partij is hetzij als expert zijn mening kan laten schitteren. Een tweede reden die de mediadeskundigen aanvoeren voor de digitale persbelangstelling heeft te maken met de menselijke 'gemakszucht' die ook journalisten niet vreemd is. Waarom zou een journalist zich druk maken over een neutraal artikel, waarin hij de context zorgvuldig moet achterhalen en weergeven, terwijl juist in conflictsituaties de elkaar bestrijdende partijen gedetailleerde achtergrondinformatie over de ontstane situatie als hapklare brokken gereedzetten.

Welke lessen kunnen wij als accountants hier nu uit trekken? Om te beginnen denk ik dat in geval van calamiteiten een transparantere opstelling van het beroep noodzakelijk is. Veelal hebben accountants de neiging om in geval van een calamiteit er het zwijgen toe te doen. Ik denk evenwel dat de pers absoluut openstaat voor de opinie van de betrokken accountant, en dat het voor de balans in de publieke opinie ook goed is om die tegenreactie maar zo snel mogelijk te geven, voorzover mogelijk natuurlijk binnen de grenzen van de geheimhouding. En aan de andere kant zou ook de beroepsorganisatie er goed aan doen om het voortouw te nemen in de discussie, door snel een onderzoek naar de rol van de betrokken accountants aan te kondigen en uit te voeren.

Een tweede belangrijke les wat mij betreft is de nadrukkelijke behoefte aan de rol van de accountant als 'elite expert'. Een positie waar naar mijn mening meer maatschappelijk rendement uit kan worden gehaald. Vanuit onze positie zijn wij niet alleen in staat om verstandige dingen te roepen over de accountanstwetgeving, IAS, of corporate governance. Maar toch zeker ook over maatschappelijk zeer relevante onderwerpen als de kosten van de gezondheidszorg, of de betaalbaarheid op termijn van ons pensioenstelsel? Accountants(organisaties) hebben ten aanzien van dit soort vraagstukken data en inzichten die een aanzienlijke bijdrage aan dergelijke maatschappelijke discussies zouden kunnen leveren. Door die kennis te ontsluiten en beschikbaar te stellen voor een breed publiek realiseren wij naar mijn mening een grotere maatschappelijke erkenning dan door welke publieke opvoedingscampagne ten aanzien van de beperkingen van onze verantwoordelijkheid dan ook! Accountant, laat van je horen! 